Benjamin, C.M., Anionwu, E.N., Kristoffersson, U., Kate, L.P. ten, Plass, A.M.C., Nippert, I., Julian-Reynier, C., Harris, H.J., Schmidtke, J., Challen, K., Calefato, J.M., Waterman, C., Powell, E., Harris, R. Educational priorities and current involvement in genetic practice: a surveyef 7 midwives in the Netherlands, UK and Sweden. Midwifery: 2009, 25(5), 483-499

\begin{tabular}{l|l}
\hline Postprint Version & 1.0 \\
\hline Journal website & http://www.sciencedirect.com/science/article/pii/S0266613807001076 \\
\hline Pubmed link & http://www.ncbi.nlm.nih.gov/pubmed/18068279 \\
\hline DOI & $10.1016 / j . m i d w .2007 .08 .003$ \\
\hline
\end{tabular}

This is a NIVEL certified Post Print, more info at http://www.nivel.eu

\title{
Educational priorities and current involvement in genetic practice: a survey of midwives in the Netherlands, UK and Sweden.
}

\author{
CAROLINE M. Benjamin, RGN, PhD ${ }^{A, B}$ (PROJeCt MANAGER \& Registered GENETIC \\ Counsellor), ElizABeth N. Anionwu, RGN, PHD ${ }^{\complement}$ (Professor OF Nursing \& HeAD of \\ the Mary Seacole Centre for Nursing Practice), Ulf Kristoffersson, MD, PhD \\ (Associate Professor \& SENIOR CONSUltant), LeO P. TEN KATE, MD, PhD ${ }^{\mathrm{E}}$ \\ (Professor of Clinical Genetics), Anne Marie C. Plass, PhD ${ }^{\mathrm{E}}$ (Senior Researcher), \\ IRMGARD NiPPERT, PHD ${ }^{\mathrm{F}}$ (UNIVERSITY PROFESSOR (WOMEN'S HEALTH RESEARCH)), \\ Claire Julian-REYNIER, MD ${ }^{\mathrm{G}}$ (Director of RESEARCH), HILARY J. HARRIS, MBChB, \\ FRCGP $^{A}$ (GENERAL PRACTITIONER), JOERG SCHMIDTKE, MD ${ }^{\mathrm{H}}$ (PROFESSOR OF MEDICAL

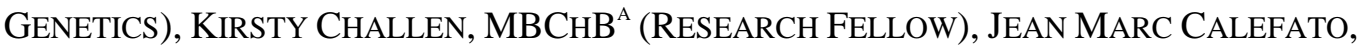 \\ BSC $^{G}$ (STATISTICIAN), CHRISTINE WATERMAN, BSC ${ }^{A}$ (RESEARCH ASSOCIATE), EILEEN \\ POWELL, RM, MA ${ }^{\mathrm{C}}$ (SENIOR LECTURER), RODNEY HARRIS, MD, FRCP ${ }^{\mathrm{A}}$ (PROFESSOR \\ (EMERITUS) MEDICAL GENETICS), ON BEHALF OF THE GENED RESEARCH GROUP \\ ${ }^{a}$ GenEd Coordinating Centre, University of Manchester, Manchester, UK \\ ${ }^{\mathrm{b}}$ School of Nursing, Birmingham University and Liverpool Women's NHS Foundation Trust, \\ UK \\ ${ }^{c}$ Faculty of Health and Human Sciences, Thames Valley University, London, UK \\ ${ }^{d}$ Department of Clinical Genetics, University Hospital, Lund, Sweden \\ ${ }^{\mathrm{e}}$ Department of Clinical Genetics, EMGO Institute, VU University Medical Centre, \\ Amsterdam, The Netherlands \\ ${ }^{\dagger}$ Frauengesundheitsforschung/Institut für Humangenetik, Universitätsklinikum Münster, \\ Münster, Germany \\ g INSERM, UMR379, Institut Paoli-Calmettes, Marseille, France \\ ${ }^{\mathrm{h}}$ Institut für Humangenetik, Medizinische Hochschule Hannover, Hannover, Germany
}

\begin{abstract}
Objective: to investigate whether practising midwives are adequately prepared to integrate genetic information into their practice.

Design: a cross-sectional, postal, structured questionnaire survey was sent to practising midwives.

Setting: practising midwives from the Netherlands (NL), Sweden (SE) and the United Kingdom (UK).

Participants: 1021 replies were received, achieving a response rate of $62 \%$.

Findings: 79\% (799/1015) of midwives reported attending courses with some 'genetic content' during their initial training. Sixty-eight per cent (533/784) judged this to have been useful for clinical practice. Variation was seen between
\end{abstract}


Benjamin, C.M., Anionwu, E.N., Kristoffersson, U., Kate, L.P. ten, Plass, A.M.C., Nippert, I., Julian-Reynier, C., Harris, H.J., Schmidtke, J., Challen, K., Calefato, J.M., Waterman, C., Powell, E., Harris, R. Educational priorities and current involvement in genetic practice: a surveyef midwives in the Netherlands, UK and Sweden. Midwifery: 2009, 25(5), 483-499

countries in the amount of genetic content in post-registration training (SE 87\%, NL 44\%, UK 17\%) and most was considered useful. Questions assessing clinical activity identified a current need for genetic knowledge. Midwives described low levels of self-reported confidence both in overtly genetic procedures and in everyday tasks that were underpinned by genetic knowledge. For eight of the 12 procedures, fewer than $20 \%$ of midwives considered themselves to be confident. Differences were apparent between countries. Midwives identified psychosocial, screening and risk assessment aspects of genetic education as being important to them, rather than technical aspects or genetic science.

Conclusions: given the low reported confidence with genetic issues in clinical practice, it is essential that this is addressed in terms of the amount, content and targeting of genetic education. This is especially important to ensure the success of national antenatal and baby screening programmes. The results of this study suggest that midwives would welcome further training in genetics, addressing genetic topics most relevant to their clinical practice.

\section{INTRODUCTION}

For many years, midwives have been involved in providing information to women/couples enabling tailored decision-making in relation to screening tests. However, over the last 10 years, there has been a huge increase in the number of tests available and the range of choice faced by women both prior to and during pregnancy. Recent policy initiatives in the UK and other European countries launching antenatal and neonatal screening programmes have highlighted the urgent need for research into the genetic knowledge of midwives (UK Advisory Committee on Genetic Testing, 2000; [UK Department of Health, 2000] and [UK Department of Health, 2004]; UK National Screening Committee, 2002).

As part of a 5th-Framework-funded European Grant, the GenEd (Genetic Education for Non-genetic Health Professionals) research group was established to investigate the current genetic practice and education of non-genetic health professionals, including midwives. The research group included social scientists, nurses, clinical geneticists, general practitioners, educationalists, genetic patient support groups and a senior lecturer in midwifery (Challen et al., 2005). Midwives had responsibility for managing the care of women throughout pregnancy in three of the countries covered by the GenEd study. The Netherlands (NL), United Kingdom (UK) and Sweden (SE) were therefore selected for further study.

GenEd Phase 1 focused on exploring existing education for doctors, nurses and midwives (Challen et al., 2006; Harris et al., 2006; Henriksson and Kristoffersson, 2006; Julian-Reynier and Arnaud, 2006; Plass et al., 2006; Schmidtke et al., 2006). This paper reports on the midwifery results from Phase 2, the health professionals' questionnaire survey, which examined the self-reported behaviours and educational priorities of primary care providers in situations where genetics is relevant.

\section{Genetics within clinical practice}

As the main point of contact for health-care concerns during pregnancy, women and their families expect midwives to be an informed source of relevant information and 
Benjamin, C.M., Anionwu, E.N., Kristoffersson, U., Kate, L.P. ten, Plass, A.M.C., Nippert, I., Julian-Reynier, C., Harris, H.J., Schmidtke, J., Challen, K., Calefato, J.M., Waterman, C., Powell, E., Harris, R. Educational priorities and current involvement in genetic practice: a surveyef midwives in the Netherlands, UK and Sweden. Midwifery: 2009, 25(5), 483-499

to be able to access up-to-date literature. The ability of non-genetic health-care providers to deliver appropriate and timely genetic information to women/couples is the subject of ongoing debate (Greendale and Pyertitz, 2001; Guttmacher et al., 2001). The UK Government has recognised the requirement for genetic information and technology to be available not only in specialist centres but also in primary care, and for the development of a strategy for genetic education (Burton, 2003; UK Department of Health, 2003).

Previous research has concentrated on the information and counselling provided by midwives in relation to prenatal screening. Over 10 years ago, it was reported that midwives were not confident providing information relating to second trimester serum screening, and women receiving counselling about testing for fetal abnormality received little information about the condition being screened for, the test process and the implications of possible results (Marteau et al., 1992; Khalid et al., 1994). More recently, a European study has demonstrated that some women undergoing first trimester screening by nuchal translucency measurements were uninformed and unprepared (Kooij et al., 2001; Weinans et al., 2004). Tyzack and Wallace (2003) showed that $40 \%$ of midwives providing information and counselling for Down's syndrome screening did not feel confident about explaining the test, and $46 \%$ felt that they had not received adequate education about the test. They investigated the knowledge base relating to Down's syndrome screening and found that this was variable even amongst those midwives who regularly counsel women about these tests, falling short of the recommended guidelines for ethical provision of genetic tests (Nuffield Council on Bioethics, 1993; Tyzack and Wallace, 2003). Further studies have shown that midwives providing screening for haemoglobinopathies, Down's syndrome and neural tube defects are poorly prepared for the role, and have difficulties giving uncertain information to women, often allowing their own biases or experience to frame the discussion (Dyson et al., 1996; Bramwell and Carter, 2001; Dyson, 2005).

A postal questionnaire study of 817 midwives in the West Midlands, UK (51\% response rate) showed that midwives rated genetic activity as very important to their current practice, and reported low personal confidence in a number of genetic scenarios; 89\% expressed an interest in taking a course in genetics (Bennett et al., 2004; Metcalfe et al., 2007).

In 1999, a National Confidential Enquiry into counselling for genetic disorders by non-geneticists reviewed over 1000 genetic events (e.g. cases of Down's syndrome, neural tube defects, cystic fibrosis, thyroid cancer and thalassaemia), and found that clinicians (including some midwives) concentrated on clinical care but often failed to document counselling and information on reproductive choice and disease prevention (Harris et al., 1999).

\section{Educational preparation}

A recent survey of UK post-registration nursing and midwifery programmes showed that inclusion of genetics in the curriculum was variable, with 19 of the 38 higher education institutes stating that they did not include any genetics in their curriculum at post-registration level. The organisations that provided midwifery education, but without a specific module in genetics, reported that a 'smattering' of genetics was included in the programme. In reality, this meant that the content was left to individual teachers. The majority of respondents felt that genetics was not seen as 
Benjamin, C.M., Anionwu, E.N., Kristoffersson, U., Kate, L.P. ten, Plass, A.M.C., Nippert, I., Julian-Reynier, C., Harris, H.J., Schmidtke, J., Challen, K., Calefato, J.M., Waterman, C., Powell, E., Harris, R. Educational priorities and current involvement in genetic practice: a surveyef 7 midwives in the Netherlands, UK and Sweden. Midwifery: 2009, 25(5), 483-499

pertinent to nursing, midwifery or health visiting, as re-inforced by this quote from a tutor, 'some course leaders did not feel genetics were relevant' (Metcalfe and Burton, 2003). In a survey of pre-registration nursing and midwifery programmes in the UK, it seems that attitudes may be changing. The educators indicated that they were aware of the deficits in genetic educational provision and were keen to support the development of genetic competence within the nursing and midwifery professions (Kirk and Tonkin, 2006). In the NL, genetics is included in the midwifery preregistration curriculum (Plass et al., 2006).

In 1998, a survey of pre-registration nursing and midwifery programmes in the UK showed that although genetics was included in the majority of programmes, the content was usually 10 hours or less (Kirk, 1999). In the USA, SE and the NL, the situation is similar (Anderson, 1996; Monson et al., 2000; Challen et al., 2005; Henriksson and Kristoffersson, 2006; Plass et al., 2006). A recent literature review of genetic education confirmed agreement on the relevance of genetic education for nursing and midwifery practice, but demonstrated a widespread deficit in the knowledge and skills of practising nursing and midwifery professionals (Burke and Kirk, 2006).

Over the last 5 years, there have been a number of pivotal position statements and consensus documents developing competencies in genetics for nurses and midwives. The National Coalition of Health Professional Education in Genetics in the USA has issued a set of competencies for practising health professionals (National Coalition for Health Professional Education in Genetics, 2000). More recently, competencies in genetic knowledge, skills and attitudes for both newly registered nurses, midwives and health visitors and those working at a specialty level have been developed in the UK through an expert panel process (Kirk et al., 2003a). In New Zealand, despite many calls to increase the genetic content in midwifery programmes, it still remains small (Nicol, 2002). In Japan, Canada and Singapore, the situation is similar (Mizoguchi et al., 2000; Yong et al., 2003; Thompson, 2004). A working party on behalf of the Director General Research in the European Commission issued a position paper calling for ethical genetic testing and defined good clinical practice (McNally et al., 2004). To highlight the need for genetic education at a global level, the International Council of Nurses published a monograph, 'Nursing and midwifery leadership: 21st Century genetics for global health', providing guidance on integrating genetics into nursing and midwifery research, education and practice (Feetham et al., 2005). With the increasing application of genetics to health and illness, midwives will be expected to have the knowledge, skills and abilities to integrate genetics into their research, education and practice.

\section{METHODS}

The study questionnaire (containing 158 items) was designed by a multidisciplinary consortium of experts composed of clinical geneticists $(n=5)$, general and hospital practitioners $(n=2)$, a senior lecturer in midwifery $(n=1)$, nurses $(n=2)$, representatives of patients' associations $(n=2)$ and methodologists $(n=5)$. Each country was involved in the questionnaire design, which was undertaken in specific workshops. The first draft contained as many items as possible to maximise content validity and relevance to the field of genetics in clinical practice. The questionnaire was translated and back-translated, piloted and amended to ensure consistency across countries. The master study questionnaire was adapted for each of the four 
Benjamin, C.M., Anionwu, E.N., Kristoffersson, U., Kate, L.P. ten, Plass, A.M.C., Nippert, I., Julian-Reynier, C., Harris, H.J., Schmidtke, J., Challen, K., Calefato, J.M., Waterman, C., Powell, E., Harris, R. Educational priorities and current involvement in genetic practice: a surveyef midwives in the Netherlands, UK and Sweden. Midwifery: 2009, 25(5), 483-499

professional disciplines (obstetricians, paediatricians, general practitioners and midwives). Practising and academic midwives were consulted about the relevance of content and layout for the midwife-specific questionnaire. The questionnaire covered areas such as basic demographics, education in genetics, a clinical scenario, current clinical practice, confidence with clinical activity that has a genetic component, and preferences for priorities for their own genetic education. The results of the following questions are presented in this paper.

Midwives were asked:

How often in their clinical practice did genetics present as an element of a case? This was designed to gauge self-awareness of the impact of genetic conditions on current midwifery practice.

How often had they been consulted by a client presenting with any of 12 possible genetic scenarios? They were asked to give examples, where they could, of the genetic conditions they had been consulted about in the last 12 months.

-To indicate how often they performed or directly ordered 13 procedures, each of which was chosen for inclusion as it had a genetic informational, skill or knowledge element.

- To rate their own confidence in performing each of 12 clinical procedures.

-To rate 30 items, each on a five-point scale of lowest priority (1) to highest priority (5), for their preference for priorities in their own genetic education.

A postal survey was conducted using Dillman's total design method, and a small monetary incentive for the respondents ( $€ 10$ or $£ 5$ ) was provided (Crosby et al., 1989). In total, 1700 midwives were sent a questionnaire between March and May 2004 and at least one reminder was posted. Some countries organised a second postal reminder and/or a telephone call to achieve, if possible, a minimum response of 200 midwives per country. This number was calculated for a precision (confidence interval) of $5 \%$ for a $95 \%$ level of confidence that a random sample had been achieved.

In the UK, the midwives were selected at random from members of the Royal College of Midwives. In the NL, they were selected at random from the Institute for Health Services Research, and in SE from a commercial listing MedBase list. The responses were entered into a Statistical Package for the Social Sciences Version 11 using SNAP Version 7 questionnaire and scanning software. All analyses were undertaken to one decimal place. Whole percentages are presented in the paper for clarity; for measures of association, a p-value $\leqslant 0.05$ was taken to be statistically significant. The construction of subscales from the 30-item educational priority responses was performed by factor analysis.

\section{FINDINGS}

The overall response rate was 62\% (1021/1648): NL 71\%, SE 61\% and UK 56\% (Table 1). The respondents were representative of national profiles in terms of age and gender (most were females). Ages ranged from 23 to 70 years with a median age of 50 years. Years in practice ranged from less than 1 to 45 years (median 20 years). Participants worked in a variety of urban and rural populations and represented most regional areas. The respondents were mainly experienced practitioners with an average period of practice of 15 years, and 79\% stated having appointments with 
Benjamin, C.M., Anionwu, E.N., Kristoffersson, U., Kate, L.P. ten, Plass, A.M.C., Nippert, I., Julian-Reynier, C., Harris, H.J., Schmidtke, J., Challen, K., Calefato, J.M., Waterman, C., Powell, E., Harris, R. Educational priorities and current involvement in genetic practice: a surveyef 7 midwives in the Netherlands, UK and Sweden. Midwifery: 2009, 25(5), 483-499

fewer than 50 women each week. SE has an older population of practising midwives than the NL and the UK. Midwives in the UK and SE tended to see fewer women per week than midwives in the NL; 54\% of UK midwives reported seeing between 0 and 25 women per week compared with $34 \%$ of midwives from SE and 11\% of midwives from the NL.

\section{[TABLE 1]}

\section{Midwives' education in genetics}

When respondents were asked to self-report if they had attended any courses that contained 'genetic content' in their education to date, 90\% said that they had received some education at some point in their career, either during their initial midwifery training, post-registration courses or independent study or seminars. Table 2 shows the stage at which this training was provided and also the self-rated usefulness for current practice. The majority of respondents (79\%) received genetic education during their initial midwifery training, although there were differences between countries (NL 92\%, SE 68\% and UK 75\%). Overall, 68\% felt that this initial training had been useful for current practice. Eighty-seven per cent of midwives from SE stated that they had received genetic education during post-registration training, which is in contrast to $17.4 \%$ of UK midwives and $44 \%$ of midwives from the NL. The usefulness of post-registration training varied between countries, with nearly all respondents in the NL and UK reporting that this had been useful. Midwives from SE rated the usefulness of training lower, stating that only 31\% of initial training and $59 \%$ of post-registration education had been useful. Relatively little education seems to have taken place during continuing professional development (16\% across the whole sample), but this was highly valued in all three countries (NL 100\%, SE 83\% and UK 96\%).

\section{[TABLE 2]}

\section{Genetic information in current midwifery practice}

To assess self-reported awareness of how often genetic issues arise in midwifery practice, the following subjective question was asked: 'how often in clinical practice does genetics present as an element of a case?' The results indicate that half of midwives from the NL reported seeing cases with a genetic element once a month or more, in contrast with just $25 \%$ and $21 \%$ of midwives from the UK and SE, respectively (Fig. 1). Respondents were asked to give examples, where they could, of the genetic conditions they had been consulted about in the last 12 months. The top eight conditions are presented in Table 3. Over 60 other conditions or malformations were given as examples, but none of these contributed more than $3 \%$ of the total. There was little variation in the genetic conditions given in the examples between countries.

\section{[FIGURE 1-TABLE 3]}

To assess the types of clinical issues encountered in practice specifically, the midwives were asked if they had cared for an individual or couple experiencing one of 12 scenarios in the last 12 months. The most frequently reported scenarios (the top four, all reported by more than $50 \%$ of the sample) included situations that may involve genetic factors, although a genetic diagnosis has not been explicitly stated 
Benjamin, C.M., Anionwu, E.N., Kristoffersson, U., Kate, L.P. ten, Plass, A.M.C., Nippert, I., Julian-Reynier, C., Harris, H.J., Schmidtke, J., Challen, K., Calefato, J.M., Waterman, C., Powell, E., Harris, R. Educational priorities and current involvement in genetic practice: a survey ef 7 midwives in the Netherlands, UK and Sweden. Midwifery: 2009, 25(5), 483-499

(Fig. 2). The bottom five scenarios (all encountered by less than $30 \%$ of the sample) consisted of situations where the words 'genetic', 'DNA' or 'pedigree' had been indicated on the questionnaire. Fewer midwives in SE than in the NL or the UK cared for women with a fetal abnormality, family history of disease, or positive maternal serum or nuchal translucency test. Midwives in all three countries showed similar rates of care regarding recurrent spontaneous abortions, fetal loss and birth defects.

\section{[FIGURE 2]}

Fig. 3 demonstrates how often midwives performed or ordered 13 procedures (Fig. 3a-m). The data are displayed by making the assumption that a procedure forms part of their current practice, i.e. 'regularly performed' if midwives indicated having performed/ordered it at least once a month. The top six procedures (a-f) were those reported as occurring regularly by over $30 \%$ of the midwives. They did not include the word 'genetics' in their description and, at first, may not seem associated with genetic information; for example, the first neonatal/baby examination or the 18-20week fetal ultrasound examination. However, the rationale behind using these procedures in this survey was to highlight that these can be used to identify fetal conditions, often genetic in nature. Other procedures ( $\mathrm{g}-\mathrm{m})$, reported as being performed less regularly, had a more direct association with genetic information, such as recording family history details, antenatal maternal serum screening, discussing baby screening blood tests, ordering amniocentesis or chorionic villus sampling, and giving risk information based on family history. The frequency of Procedure h (referral to genetic services for reproductive issues) was low; only $10 \%$ of respondents had referred women or couples more than once or twice a month, and $27 \%, 76 \%$ and $53 \%$ of midwives from SE, the NL and the UK, respectively, stated that they had never made a referral. Taking the whole sample, $65 \%$ of respondents reported recording family history details less regularly (Procedure b). Midwives from SE seemed to record family history details least regularly (27\% stated 'never') compared with the other countries (NL 9\% and UK 8\%). Of interest, although many respondents stated taking family history details, only $6 \%$ of the total midwives had regularly drawn a pedigree, including affected and unaffected family members (Procedure b).

\section{[FIGURE 3]}

When asked a separate question about how often midwives or their institutions ask the ethnicity of women, only $44 \%$ of midwives from SE responded 'often' or 'always', in contrast to the more comprehensive practice in the NL (87\%) and UK (93\%) where ethnicity is nearly always asked.

\section{Midwives' confidence in genetic procedures}

Midwives were asked to indicate their confidence on a four-item response scale (very confident/confident/somewhat confident/not confident) in performing 12 procedures/skills that may require some genetic knowledge. Generally, midwives did not feel confident about most procedures. However, there was variation between countries. The overall results fall into three main groups (Fig. 4). Group A includes the four procedures/skills in which the midwives felt most confident (even within this group of tasks, only between $20 \%$ and $59 \%$ of midwives stated that they were 
Benjamin, C.M., Anionwu, E.N., Kristoffersson, U., Kate, L.P. ten, Plass, A.M.C., Nippert, I., Julian-Reynier, C., Harris, H.J., Schmidtke, J., Challen, K., Calefato, J.M., Waterman, C., Powell, E., Harris, R. Educational priorities and current involvement in genetic practice: a surveyef midwives in the Netherlands, UK and Sweden. Midwifery: 2009, 25(5), 483-499

very confident or confident): taking a family history; identifying a history of a potentially inherited condition; identifying genetic services in your area; and providing psychosocial counselling related to coping with a genetic test result. These are procedures/skills that might be expected of any practising midwife. Group B includes seven procedures/skills that are more directly related to genetic knowledge or knowledge of specific genetic conditions and/or support. Only $11-17 \%$ of midwives felt confident or very confident in these tasks. Group C, the task in which midwives felt the least confident, was counselling a young woman whose father had Huntington's disease to decide whether or not to have presymptomatic genetic testing. This is a procedure that would not normally be expected of a midwife; as expected, only $4 \%$ felt confident or very confident in this task.

\section{[FIGURE 4]}

The responses were dichotomised into 'very confident and confident' and 'somewhat confident and not confident'. There were stark differences between the countries, although all reported very low confidence in some of the procedures (Table 4). In order to compare confidence between countries, data were analysed by asking the question, 'In how many procedures/skills were the midwives reporting a nonconfident statement?' This was taken as a response of 'not confident/somewhat confident' by at least $85 \%$ of the midwives in that country. Midwives from the UK were the least confident group, with low confidence in nine of the 12 procedures/skills. Midwives from SE had low confidence in seven out of the 12 procedures/skills. The most confident group was midwives from the NL, with low confidence in three out of the 12 procedures/skills.

\section{[TABLE 4]}

Factors that could affect confidence were assessed by forward stepwise binary logistic regression analysis. This identified the variables that were significantly associated $(\mathrm{p}<0.05)$ with being very confident/confident (Table 5). Having received genetic education (in pre- or post-registration courses or as part of an independent study) was significant for the following tasks: taking a family history; identifying a family history of a potentially inherited condition; explaining autosomal inheritance; estimating risks for a recessive condition; and identifying specialist genetic services in their area. More frequent exposure to genetic issues within their own clinical practice was associated with greater confidence for 11 of the 12 procedures. Fewer years in practice was associated with more confidence in identifying a family history of a potentially inherited condition, identifying autosomal-dominant inheritance, estimating genetic risk and recognising when malformations could be genetic in origin. Longer time in practice ( $>20$ years) was significantly associated with greater confidence in identifying specialist genetic services in their area, compared with midwives with $<20$ years of experience. Age $\leqslant 50$ years was associated with less confidence for taking a family history and explaining autosomal inheritance, whereas age $\geqslant 50$ years was associated with more confidence for identifying relevant patient information material and identifying support groups for genetic conditions. Having a practice seeing $>50$ women per week was associated with more confidence for taking a family history, explaining autosomal inheritance and providing psychosocial counselling. 
Benjamin, C.M., Anionwu, E.N., Kristoffersson, U., Kate, L.P. ten, Plass, A.M.C., Nippert, I., Julian-Reynier, C., Harris, H.J., Schmidtke, J., Challen, K., Calefato, J.M., Waterman, C., Powell, E., Harris, R. Educational priorities and current involvement in genetic practice: a surveyef midwives in the Netherlands, UK and Sweden. Midwifery: 2009, 25(5), 483-499

\section{[TABLE 5]}

\section{Educational priorities of midwives}

Midwives were asked to rate 30 items, each on a five-point scale of lowest priority (1) to highest priority (5), for their preference for priorities in their own genetic education. The responses were analysed by factor analysis and six groups of priorities were identified (Table 6). Overall importance was placed on topics most relevant for genetics in practice, with average priorities ranging between the scale points of 2.6 and 3.8 (Fig. 5). The highest ranked group was termed 'psychosocial issues and screening'. The next highest group was termed 'assessing risk and malformation'. Given that midwives often deal with congenital abnormalities and risk, this is consistent with their practice. The remaining groups were termed 'basic genetics', 'policy and population genetics', 'genetics of common disorders' and 'technical aspects of genetics/genetic science’.

\section{[TABLE 6 - FIGURE 5]}

\section{Discussion}

Research into the amount and content of genetic information taught at preregistration level for nurses and midwives in the UK has shown that this is usually less than 10 hours (Kirk, 1999). This is the first multicountry study that has assessed whether midwives have adequate preparation to integrate genetics into their practice. The results are of concern as many countries are expecting midwives to undertake new procedures related to genetic information. The results show that the majority of midwives have received some genetic content in courses at pre-registration level, and most feel that this is useful to them for current practice. However, the amount and quality of this content was not assessed.

The response rate of $62 \%$ can be considered as a good response rate for an international survey. Midwives from SE were significantly older, with $44 \%>50$ years of age, meaning that many may have received their pre-registration education in the mid-1970s when genetic knowledge was limited. This older population is the norm in SE as $80 \%$ of women are employed, giving one of the highest working female populations in Europe. Most women continue their career after having their children, helped by social regulation, thus many midwives from SE continue their work until normal retirement at 65 years of age. One reason why midwives from SE see fewer patients than midwives from the UK and the NL may be that they work part time in maternity clinics.

Post-registration courses and continuing professional development were usually seen as very useful for current practice. This may represent a response bias as midwives who were interested in genetics would have been more likely to attend such courses and also to respond to the questionnaire.

When midwives were asked the deliberately subjective question 'How often in your clinical practice does genetics present as an element in a case?', the responses of those who stated 'once a month or more' were $47 \%, 25 \%$ and $21 \%$ from midwives from the NL, the UK and SE, respectively. This indicates that practice may differ between countries or that midwives in one country may recognise the 'genetic' element to most of their work whereas others may not. The low reporting of being involved with cases with a genetic component may also be indicative that midwives 
Benjamin, C.M., Anionwu, E.N., Kristoffersson, U., Kate, L.P. ten, Plass, A.M.C., Nippert, I., Julian-Reynier, C., Harris, H.J., Schmidtke, J., Challen, K., Calefato, J.M., Waterman, C., Powell, midwives in the Netherlands, UK and Sweden. Midwifery: 2009, 25(5), 483-499

from SE may not be as involved as midwives from the UK or the NL in pregnancies where a genetic issue has been identified. This could be due to the role of the midwife in SE and how involved they are in high-risk pregnancies; within SE, there is no national serum screening programme outside of specialist health centres, and midwives are rarely involved in this service.

The empirical evidence from the questions asking about clinical practice demonstrates that most midwives are actually actively engaged in procedures that require genetic knowledge and skills. Procedures that did not explicitly mention a genetic condition, such as discussing baby screening blood tests, were performed regularly in contrast to ordering a DNA test. This could indicate that midwives perceive that they do not come into contact with many DNA tests or confirmed genetic conditions, and could miss the relevance of genetics to those procedures occurring frequently in their current clinical practice. This may give the impression that midwives are not actively engaged in the new genetic technology. However, routine clinical practice, such as recording family history details, ethnicity and performing maternal serum screening, involves 'genetic screening tests' in the wider sense that they can identify individuals at risk. Women need to be prepared and adequately informed about the consequences of such screening. However, procedures such as taking a DNA sample would not be appropriate for a midwife in the countries studied, and it should be sufficient that they know how to refer to other health professionals.

This study found that the majority of midwives from the NL and the UK always ask about ethnicity. This is in contrast to the findings of Dyson (2005) who reported, from his interviews of haemoglobinopathy counsellors in the UK, that 'Counsellors suggest that midwives generally lack confidence in asking an ethnicity question for the purposes of selective screening for sickle cell/thalassaemia. Both pre-registration and continuing professional education need to address issues of ethnicity, the myth of 'race', racism, racialisation and cultural competency both in general and in specific relation to the haemoglobinopathies' (Dyson, 2005). What is not clear from the present survey is whether the midwives participating in this survey were able to analyse the ethnicity information correctly to facilitate screening decisions. The finding that $56 \%$ of midwives from SE ask about ethnicity 'sometimes' or 'never' could well reflect the fact that SE has only recently had an increase in immigration from high-risk areas and has no national policy on haemoglobinopathy screening, and thus there is low awareness of problems associated with ethnicity and baby disease.

When midwives were asked about the frequency of consultations, the top four responses, all reported by more than $50 \%$ of the group (see Fig. 3), included situations where, although a genetic diagnosis has not been stated explicitly, it may still be caused by or involve genetic factors. Tasks more obviously associated with genetic information, such as ordering or giving risk information based on a DNA test, were performed very infrequently ( $<5 \%$ of midwives). This survey shows that midwives, although not frequently involved in taking genetic blood tests, do frequently perform tasks and report caring for women by taking family history details and undertaking neonatal examinations. They also care for women who have experienced a fetal loss, which often could have genetic relevance to the family, strengthening the argument for genetic education. 
Benjamin, C.M., Anionwu, E.N., Kristoffersson, U., Kate, L.P. ten, Plass, A.M.C., Nippert, I., Julian-Reynier, C., Harris, H.J., Schmidtke, J., Challen, K., Calefato, J.M., Waterman, C., Powell, $E_{\text {., Harris, R. Educational priorities and current involvement in genetic practice: a survey } f^{-}}$ midwives in the Netherlands, UK and Sweden. Midwifery: 2009, 25(5), 483-499

It is clear that midwives come into contact most frequently with eight genetic conditions (Table 3). This study therefore provides powerful evidence that educational initiatives for midwives should target these areas. In the UK, the Professional Education for Genetic Assessment and Screening (PEGASUS) website (http://www.pegasus.nhs.uk) has been created recently to offer educational resources for midwives involved in implementing antenatal and neonatal screening policies (UK National Screening Committee, 2006). Initially focusing on sickle cell and thalassaemia disorders, it is also relevant for conditions such as cystic fibrosis. These eight conditions are similar to those found by Burton in her focus group work (Burton, 2002).

When trying to raise awareness of the importance of education in genetics within the midwifery curriculum, and for tutors and faculty to appreciate the importance of genetics to underpin everyday midwifery care, it is essential to link genetics with everyday clinical practice, as educators are still debating if it is a necessity or a luxury (Pfeil and Chi-Meih, 2005). A UK study indicated that it was clear that most midwifery tutors did not feel that genetics needed to be included in the curriculum (Metcalfe and Burton, 2003). This differs from the finding of more recent research where genetics is gaining more support from midwife educators, and there is an acknowledgement that genetic education is essential (Kirk and Tonkin, 2006). A major finding of this study was that midwives lack confidence in many of the procedures they are expected to perform as part of routine client care. In general, midwives who have received some genetic education, have trained recently, who see more women a week, who are younger, and those currently seeing a high proportion of genetic conditions in current practice are the most confident in genetic skills. Midwives from the NL were the most confident of all the three countries. It must be stressed that confidence is not necessarily a marker of competence. It still remains unclear whether midwives are aware of how genetic information and technology can be used for the benefit of their client, and if they are aware of the possible harm that could be caused by inappropriate use of information. In particular, it should be noted that all midwives from the NL receive genetic education as part of their training programme. They are more likely to see a genetic element and feel more confident than midwives from SE and the UK.

There are now many curriculum recommendations in the literature suggesting the integration of genetics into midwifery educational programmes (HRSA Expert Panel Report on Genetics and Nursing, 2000; Mizoguchi et al., 2000; Lea, 2002; [Kirk et al., 2003a] and [Kirk et al., 2003b]; Hetteberg and Prows, 2004; Horner et al., 2004; Kirk and Tonkin, 2006; Lewis et al., 2006). Those by Kirk et al. (2003b) involved an expert panel process including midwifery leaders. The UK study by Burton used focus groups of professionals to help define the strategy for education in England (Burton, 2003). What remains unclear is how currently practising midwives are going to access this education, as research has shown that midwifery tutors have often not received adequate preparation to undertake this teaching (Metcalfe and Burton, 2003). A new report in the UK has provided a survey of the needs of UK educators in delivering a genetic competence framework, and in conjunction with the strategies of the National Genetics Education and Development Centre, this should help to facilitate educational provision (Kirk and Tonkin, 2006).

This study has provided educationalists with a needs assessment analysis, placing the educational topic of 'psychosocial issues and screening' highest. It seems relevant 
Benjamin, C.M., Anionwu, E.N., Kristoffersson, U., Kate, L.P. ten, Plass, A.M.C., Nippert, I., Julian-Reynier, C., Harris, H.J., Schmidtke, J., Challen, K., Calefato, J.M., Waterman, C., Powell, E., Harris, R. Educational priorities and current involvement in genetic practice: a surveyef midwives in the Netherlands, UK and Sweden. Midwifery: 2009, 25(5), 483-499

that this was given the highest priority at this time when there is much attention on pre- and antenatal population screening programmes. It is clear that although midwives prioritise genetics for their education, the more practical areas of dealing with current clinical care, such as screening and risk assessment, are prioritised over possible technical elements of genetic science.

A national strategy for health professional education in genetics has been developed for England (Burton, 2003), and is being facilitated by the National Genetics Education and Development Centre (National Genetics Education and Development Centre, 2005). The authors are unaware of similar strategies in other European countries. The specialty of clinical genetics is not recognised within all European countries, and provision of genetic counselling services across Europe varies greatly (European Society of Human Genetics Public and Professional Policy Committee, 2003). A recent series of articles in the 'Journal of Nursing Scholarship' has highlighted the difficulty in ensuring that nurses and midwives contribute to policy discussions surrounding the use of the emerging genomic science (Feetham et al., 2005). A useful educational resource specifically for midwives has been published recently (Little and Lewis, 2005), and in 2006, the Progress Trust and the Royal College of Nursing collaborated to produce 'A guide to genetics' (Pembrey, 2006).

\section{CONCLUSION}

Midwives should be sufficiently skilled and knowledgeable to provide support for women who could possibly be at risk and where genetic information might be of benefit. This paper has shown that the majority of this group of midwives reported that they had received some genetic education, either during pre- or post-registration programmes, which they felt had been useful for their clinical practice, and they are currently actively engaged in using genetic information and skills to support their practice. Their confidence remains low and there is a question regarding whether they are competent to undertake the additional skills and procedures required due to the increase in screening programmes for genetic conditions. This research has highlighted the urgent need to develop educational strategies and include genetics in the curriculum, both at pre-registration and post-registration level. The results make a clear case for the inclusion of genetics in continuing education as a priority. They indicate that genetic information may be seen to be more relevant at this stage of the midwives' career where there is more identification of genetic skills and how they relate to clinical responsibilities.

\section{ACKNOWLEDGEMENTS}

The authors acknowledge the help of the midwives who completed the surveys and funding from the EU 5th Framework Accompanying Measure QLG4-CT-200130216.

\section{REFERENCES}

Anderson, 1996G. Anderson The evolution and status of genetics education in nursing in the United States 1983-1995 Journal of Nursing Scholarship, 28 (2) (1996), pp. 101-106

Bennett et al., 2004C. Bennett, J. Haydon, A. Metcalfe, P. Farndon What do midwives think about genetics? The implications for genetics education of midwives' views on the importance of genetics and their rating of their own competence Journal of Medical Genetics, 41 (Suppl. 1) (2004), p. S86 
Benjamin, C.M., Anionwu, E.N., Kristoffersson, U., Kate, L.P. ten, Plass, A.M.C., Nippert, I., Julian-Reynier, C., Harris, H.J., Schmidtke, J., Challen, K., Calefato, J.M., Waterman, C., Powell, E., Harris, R. Educational priorities and current involvement in genetic practice: a survey $f$ midwives in the Netherlands, UK and Sweden. Midwifery: 2009, 25(5), 483-499

Bramwell and Carter, 2001R. Bramwell, D. Carter An exploration of midwives' and obstetricians' knowledge of genetic screening in pregnancy and their perception of appropriate counseling Midwifery, 17 (2001), pp. 133-141

Burke and Kirk, 2006S. Burke, M. Kirk Genetics education in the nursing profession: literature review Journal of Advanced Nursing, 54 (2006), pp. 228-237

Burton, 2002H. Burton Education in Genetics for Health Professionals: Report to the Wellcome Trust Public Health Genetics Unit, Cambridge (2002)

Burton, 2003 H. Burton Addressing Genetics Delivering Health: Report to the Wellcome Trust and the Department of Health Public Health Genetics Unit, Cambridge (2003) Challen et al., 2005 K. Challen, H. Harris, C. Julian-Reynier et al. Genetic education and nongenetic health professionals: education providers and curricula in Europe Genetics in Medicine, 7 (2005), pp. 302-310

Challen et al., 2006 K. Challen, H. Harris, C.M. Benjamin, R. Harris Genetics teaching for non-geneticist health care professionals in the UK Community Genetics, 9 (2006), pp. 251259

Crosby et al., 1989 F. Crosby, M.R. Ventura, M.J. Feldman Examination of a survey methodology: Dillman's total design method Nursing Research, 38 (1989), pp. 56-58

Dyson, 2005 S. Dyson Ethnicity and Screening for Sickle Cell/Thalassaemia. Lessons for Practice from the Voices of Experience Elsevier, Churchill Livingstone, London (2005)

Dyson et al., 1996 S. Dyson, A. Fielder, M. Kirkham Midwives' and senior student midwives' knowledge of haemoglobinopathies in England Midwifery, 12 (1996), pp. 23-30

European Society of Human Genetics Public and Professional Policy Committee, 2003 European Society of Human Genetics Public and Professional Policy Committee Provision of genetic services in Europe: current practices and issues European Journal of Human Genetics, 11 (Suppl. 2) (2003), pp. S2-S4

Feetham et al., 2005 S. Feetham, E.J. Thomson, A.S. Hinshaw Nursing leadership in genomics for health and society Journal of Nursing Scholarship, 37 (2005), pp. 102-110

Greendale and Pyertitz, 2001K. Greendale, R. Pyertitz Empowering primary care professionals in medical genetics: how soon? How fast? How far? American Journal of Medical Genetics, 106 (2001), pp. 223-232

Guttmacher et al., 2001A. Guttmacher, J. Jenkins, W. Ulmann Genomic medicine: who will practice it? A call to open arms American Journal of Medical Genetics (Seminars in Medical Genetics), 106 (2001), pp. 216-222

Harris et al., 1999R. Harris, B. Lane, H. Harris et al.

National Confidential Enquiry into counselling for genetic disorders by non-geneticists: general recommendations and specific standards for improving care British Journal of Obstetrics and Gynaecology, 106 (1999), pp. 658-663

Harris et al., 2006R. Harris, K. Challen, C. Benjamin, H. Harris Genetic education for nongeneticist health professionals Community Genetics, 9 (2006), pp. 224-226

Henriksson and Kristoffersson, 2006K. Henriksson, U. Kristoffersson Education in medical genetics for non-genetic health care providers in Sweden Community Genetics, 9 (2006), pp. $240-245$

HRSA Expert Panel Report on Genetics and Nursing, 2000HRSA Expert Panel Report on Genetics and Nursing, 2000. Implications for education and practice, last accessed

1.10.2007〈http://ask.hrsa.gov/detail.cmf?Publd=BHP00177〉.

Hetteberg and Prows, 2004C. Hetteberg, C. Prows A checklist to assist in the integration of genetics into nursing curricula Nursing Outlook, 52 (2004), pp. 85-88

Horner et al., 2004 S. Horner, E. Abel, K. Taylor, D. Sands Using theory to guide the diffusion of genetics content in nursing curricula Nursing Outlook, 52 (2004), pp. 80-84

Julian-Reynier and Arnaud, 2006 C. Julian-Reynier, S. Arnaud France: genetics education for non-genetics health care providers Community Genetics, 9 (2006), pp. 227-237

Khalid et al., 1994 L. Khalid, S. Price, M. Barrow The attitude of midwives to maternal serum screening for Down's syndrome Public Health, 108 (1994), pp. 131-136

Kirk, 1999 M. Kirk Preparing for the future: the status of genetics education in diploma-level training courses for nurses in the UK Nurse Education Today, 19 (1999), pp. 107-115

Kirk and Tonkin, 2006 M. Kirk, E. Tonkin Genetic Education for Nursing Professional Groups: Survey of Practice and Needs of UK Educators in Delivering a Genetics 
Benjamin, C.M., Anionwu, E.N., Kristoffersson, U., Kate, L.P. ten, Plass, A.M.C., Nippert, I., Julian-Reynier, C., Harris, H.J., Schmidtke, J., Challen, K., Calefato, J.M., Waterman, C., Powell, midwives in the Netherlands, UK and Sweden. Midwifery: 2009, 25(5), 483-499

Competence Framework NHS National Genetics Education and Development Centre, Birmingham (2006)

Kirk et al., 2003a M. Kirk, K. McDonald, S. Anstey, M. Longley

Fit for Practice in the Genetics Era. A Competence Based Education Framework for Nurse, Midwives and Health Visitors University of Glamorgan, Genomics Policy Unit, Pontypridd (2003)

Kirk et al., 2003bM. Kirk, K. McDonald, M. Longley et al. Fit for Practice in the Genetics Era. A Competence Based Education Framework for Nurses, Midwives and Health Visitors University of Glamorgan, Pontypridd (2003) p. 72

Kooij et al., 2001L. Kooij, R. Grellier, F. Pechlivani, H. Toikiase Prenatal diagnosis and screening in Europe: attitudes, practices and opinions of midwives. E. Ettorre (Ed.), Before Birth, Understanding Prenatal Screening, Ashgate, Aldershot (2001)

Lea, 2002D. Lea Position statement: integrating genetics competencies into baccalaureate and advanced nursing education Nurse Outlook, 50 (2002), pp. 167-168

Lewis et al., 2006J. Lewis, K. Calzone, J. Jenkins Essential nursing competencies and curricula guidelines for genetics and genomics MCN: The American Journal of Maternal/Child Nursing, 31 (2006), pp. 146-155

Little and Lewis, 2005C. Little, J. Lewis Genetic resources for midwifery practice Journal of Midwifery \& Women's Health, 50 (2005), pp. 246-249

Marteau et al., 1992T. Marteau, J. Slack, J. Kidd, R. Shaw Presenting a routine screening test in antenatal care: practice observed Public Health, 106 (1992), pp. 136-141

McNally et al., 2004 E. McNally, A. Cambon-Thomsen, EC Expert Group

Twenty-five Recommendations on the Ethical, Legal and Social Implications of Genetic Testing European Commission, Brussels (2004)

Metcalfe and Burton, 2003 A. Metcalfe, H. Burton

Postregistration genetics education provision for nurses, midwives and health visitors in the UK Journal of Advanced Nursing, 44 (2003), pp. 350-359

Mizoguchi et al., 2000 M. Mizoguchi, H. Yokoyama, K. Wada, M. Morita, H. Ando Needs for continuing education related to genetics in nursing Journal of the Japanese Academic Nursing Association, 10 (2000), pp. 1-19

Monson et al., 2000 R. Monson, G. Anderson, F. New et al.Nursing education and genetics. Miles to go before we sleep Nursing Health Care Perspectives, 21 (2000), pp. 34-37

National Coalition for Health Professional Education in Genetics, 2000 National Coalition for Health Professional Education in Genetics, 2000. Core competencies

〈www.nchpeg.org/core/corecomps2005.pdf, last accessed 1.10.2007.

National Genetics Education and Development Centre, 2005 National Genetics Education and Development Centre, 2005. The National Genetics Education and Development Centre provides a focal point for genetics education and training in the NHS

〈www.geneticseducation.nhs.uk〉, last accessed 1.10.2007.

Nicol, $2002 \mathrm{M}$. Nicol The teaching of genetics in New Zealand undergraduate nursing programmes Nurse Education Today, 22 (2002), pp. 401-408

Nuffield Council on Bioethics, 1993 Nuffield Council on Bioethics Genetic Screening-Ethical Issues Nuffield Council on Bioethics, London (1993)

McNally et al., 2004E. McNally, A. Cambon-Thomsen, EC Expert Group Twenty-five Recommendations on the Ethical, Legal and Social Implications of Genetic Testing European Commission, Brussels (2004)

Metcalfe and Burton, 2003A. Metcalfe, H. Burton Postregistration genetics education provision for nurses, midwives and health visitors in the UK Journal of Advanced Nursing, 44 (2003), pp. 350-359

Mizoguchi et al., 2000M. Mizoguchi, H. Yokoyama, K. Wada, M. Morita, H. Ando Needs for continuing education related to genetics in nursing Journal of the Japanese Academic Nursing Association, 10 (2000), pp. 1-19

Monson et al., 2000R. Monson, G. Anderson, F. New et al. Nursing education and genetics. Miles to go before we sleep Nursing Health Care Perspectives, 21 (2000), pp. 34-37 
Benjamin, C.M., Anionwu, E.N., Kristoffersson, U., Kate, L.P. ten, Plass, A.M.C., Nippert, I., Julian-Reynier, C., Harris, H.J., Schmidtke, J., Challen, K., Calefato, J.M., Waterman, C., Powell, E., Harris, R. Educational priorities and current involvement in genetic practice: a survey ef 7 midwives in the Netherlands, UK and Sweden. Midwifery: 2009, 25(5), 483-499

National Coalition for Health Professional Education in Genetics, 2000National Coalition for Health Professional Education in Genetics, 2000. Core competencies

〈www.nchpeg.org/core/corecomps2005.pdf〉, last accessed 1.10.2007.

National Genetics Education and Development Centre, 2005National Genetics Education and Development Centre, 2005. The National Genetics Education and Development Centre provides a focal point for genetics education and training in the NHS

$\langle$ 〈www.geneticseducation.nhs.uk〉, last accessed 1.10.2007.

Nicol, 2002M. Nicol The teaching of genetics in New Zealand undergraduate nursing programmes Nurse Education Today, 22 (2002), pp. 401-408

Nuffield Council on Bioethics, 1993Nuffield Council on Bioethics Genetic Screening-Ethical Issues Nuffield Council on Bioethics, London (1993)

UK Department of Health, 2003UK Department of Health Our Inheritance, Our Future. Realising the Potential of Genetics in the NHS HMSO, London (2003) pp. 1-94

UK Department of Health, 2004UK Department of Health National Service Framework for Children, Young People and Maternity Services Department of Health, London (2004) pp. $1-44$

UK National Screening Committee, 2002UK National Screening Committee, 2002. Second Report of the UK National Screening Committee. UK National Screening Committee, London.

UK National Screening Committee, 2006UK National Screening Committee, 2006. Pegasus programme 〈http://www.pegasus.nhs.uk/frontline/menu.htm〉, last accessed 1.10.2007. Weinans et al., 2004M. Weinans, L. Kooij, M. Müller, K. Bilardo, J. Van Lith, T. Tymstra A comparison of the impact of screen-positive results obtained from ultrasound and biochemical screening for Down syndrome in the first trimester: a pilot study Prenatal Diagnosis, 24 (2004), pp. 347-351

Yong et al., 2003M. Yong, X. Zhou, S. LeeThe importance of paternal family history in hereditary breast cancer is underappreciated by health care professionals Oncology, 64 (2003), pp. 220-226

\section{TABLES AND FIGURES}

\begin{tabular}{|c|c|c|c|c|c|c|c|c|c|c|c|c|}
\hline \multirow[t]{2}{*}{ Country } & \multirow{2}{*}{$\begin{array}{c}\text { Total } \\
\text { practitioners } \\
\text { in country }\end{array}$} & \multirow{2}{*}{$\begin{array}{c}\text { Sampling } \\
\text { frame }\end{array}$} & \multirow{2}{*}{$\begin{array}{c}\text { Mailed } \\
\text { out }\end{array}$} & \multirow[t]{2}{*}{ Excluded } & \multicolumn{2}{|c|}{ Received } & \multirow{2}{*}{$\begin{array}{l}\leqslant 50 \\
\text { years }\end{array}$} & \multirow{2}{*}{$\begin{array}{l}>50 \\
\text { years }\end{array}$} & \multirow[t]{2}{*}{ Range } & \multirow{2}{*}{$\begin{array}{l}\text { Mean years } \\
\text { practising }\end{array}$} & \multirow{2}{*}{$\begin{array}{l}<50 \text { clients } \\
\text { per weeks }\end{array}$} & \multirow{2}{*}{$\begin{array}{l}\geqslant 50 \text { dients } \\
\text { per week }\end{array}$} \\
\hline & & & & & $n$ & $\%$ & & & & & & \\
\hline Netherlands (NL) & $1825^{*}$ & $1000^{+}$ & 500 & 4 & 354 & 71 & $89 \%$ & $11 \%$ & 23-65 & 12 years & $72 \%$ & $28 \%$ \\
\hline Sweden (SE) & $8724^{8}$ & $7941^{\circ}$ & 500 & 36 & 285 & 61 & $56 \%$ & $44 \%$ & $30-65$ & 19 years & $80 \%$ & $20 \%$ \\
\hline United Kingdom (UK) & $33,164^{1}$ & $31,507^{* *}$ & 700 & 12 & 382 & 56 & $83 \%$ & $17 \%$ & 23-65 & 14 years & $85 \%$ & $15 \%$ \\
\hline Total & 43,713 & 40,448 & 1700 & $52^{+1+}$ & 1021 & 62 & $p \leqslant 0.00 a^{x / 8}$ & 17, & Median 49 years & Median 20 years & $\begin{array}{r}\text { Client categories } \\
0 \\
26 \\
51 \\
101 \\
151\end{array}$ & $\begin{array}{l}\text { in questionnaire } \\
\% \\
5 \% \\
8 \% \\
.4 \% \\
9 \%\end{array}$ \\
\hline
\end{tabular}

Within each country, there were no significant differences in gender (NL $p=0.758 \mathrm{NS}, \mathrm{SE} p=0.039 \mathrm{NS}, \mathrm{UK} p=0.584 \mathrm{NS}$ ) or age of the sample and the population (NL not available, SE $p=0.175$ NS, UK $p=0.12$ )

*Source of information: Netherlands Institute for Health Services Research Practising Midwives 2003.

${ }^{\dagger}$ Registered KNOV (Royal Dutch Organisation for Midwives) membership list 2003.

Source of information: Swedish Board of Health and Welfare 2001.

'List of all licensed practitioners in Sweden MedBase owned by Pharma Marketing (September 2003).

'Source of information: UK Royal College of Midwives' list of practising members 2004

**UK Royal College of Midwives' list of practising members, excluding those who decline mailings 2004.

${ }^{\dagger+}$ Excluded due to unknown address, absence (maternity leave or illness), retired from current practice.

$\$ \chi^{2}$-test (age between countries). 
Benjamin, C.M., Anionwu, E.N., Kristoffersson, U., Kate, L.P. ten, Plass, A.M.C., Nippert, I., Julian-Reynier, C., Harris, H.J., Schmidtke, J., Challen, K., Calefato, J.M., Waterman, C., Powell, E., Harris, R. Educational priorities and current involvement in genetic practice: a surveyef 7 midwives in the Netherlands, UK and Sweden. Midwifery: 2009, 25(5), 483-499

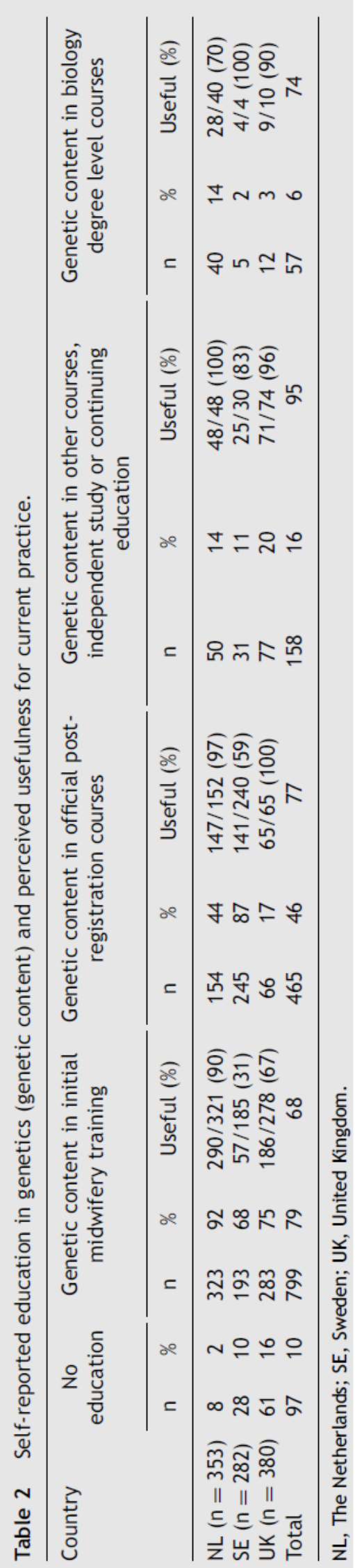


Benjamin, C.M., Anionwu, E.N., Kristoffersson, U., Kate, L.P. ten, Plass, A.M.C., Nippert, I., Julian-Reynier, C., Harris, H.J., Schmidtke, J., Challen, K., Calefato, J.M., Waterman, C., Powell, E., Harris, R. Educational priorities and current involvement in genetic practice: a surveyef 7 midwives in the Netherlands, UK and Sweden. Midwifery: 2009, 25(5), 483-499

Figure 1 Percentage of midwives indicating how often genetics present as an element of a case in clinical practice. Midwives were asked to tick the answer closest to their experience. NL ,The Netherlands; UK, United Kingdom.

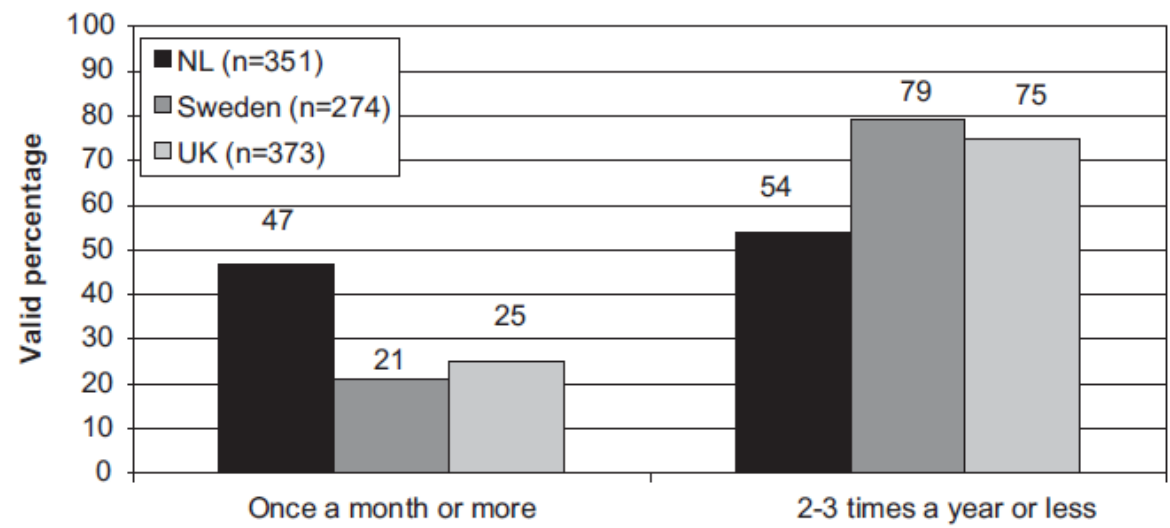

Table 3 The eight most commonly cited examples of genetic conditions provided by respondents answering five separate questions asking if they could give an example of a condition relating to clients they have seen over the last 12 months.

\begin{tabular}{|c|c|c|c|c|c|}
\hline$(n=1019)$ & $\begin{array}{l}\text { A known genetic } \\
\text { condition }\end{array}$ & $\begin{array}{l}\text { A suspected genetic } \\
\text { condition }\end{array}$ & $\begin{array}{l}\text { At risk of a genetic } \\
\text { condition }\end{array}$ & Identified as a carrier & $\begin{array}{l}\text { Give example of DNA } \\
\text { test you order }\end{array}$ \\
\hline $\begin{array}{l}\text { Examples of conditions } \\
\text { (respondents could provide } \\
\text { more than one example) }\end{array}$ & $\%$ of 261 respondents & $\%$ of 126 respondents & $\%$ of 239 respondents & $\%$ of 235 respondents & $\%$ of 24 respondents \\
\hline Cystic fibrosis & 21 cases $(8 \%)$ & 6 cases $(5 \%)$ & 23 cases $(10 \%)$ & 32 cases $(14 \%)$ & 4 cases $(17 \%)$ \\
\hline $\begin{array}{l}\text { Down's syndrome (including } \\
\text { trisomy 21) }\end{array}$ & 14 cases $(5 \%)$ & 9 cases $(7 \%)$ & 47 cases $(20 \%)$ & 8 cases $(3 \%)$ & 3 cases $(13 \%)$ \\
\hline Duchene muscular dystrophy & No cases & No cases & No cases & No cases & 2 cases $(8 \%)$ \\
\hline Haemophilia & 11 cases $(4 \%)$ & 8 cases $(6 \%)$ & 11 cases $(5 \%)$ & 22 cases $(9 \%)$ & No cases \\
\hline Neural tube defects & No cases & No cases & 11 cases $(5 \%)$ & No cases & No cases \\
\hline Heart defect ${ }^{*}$ & No cases & No cases & 9 cases $(4 \%)$ & No cases & No cases \\
\hline Sickle cell disease & 63 cases $(24 \%)$ & 30 cases $(25 \%)$ & No cases & 23 cases $(30 \%)$ & 3 cases $(13 \%)$ \\
\hline Thalassaemia & 65 cases $(25 \%)$ & 18 cases $(14 \%)$ & No cases & 43 cases $(18 \%)$ & 4 cases $(17 \%)$ \\
\hline Other examples of conditions ${ }^{\dagger}$ & 72 cases $(28 \%)$ & 37 cases $(29 \%)$ & 80 cases $(34 \%)$ & 47 cases $(20 \%)$ & 13 cases $(55 \%)$ \\
\hline
\end{tabular}

*Includes any genetic malformation of the heart.

+Over 60 other conditions/physical malformations were cited by respondents, but all with an individual frequency of less than $3 \%$.

Figure 2 Midwives' self-reported clinical practice: 'have you cared for at least one individual or couple during the last 12 months?'.

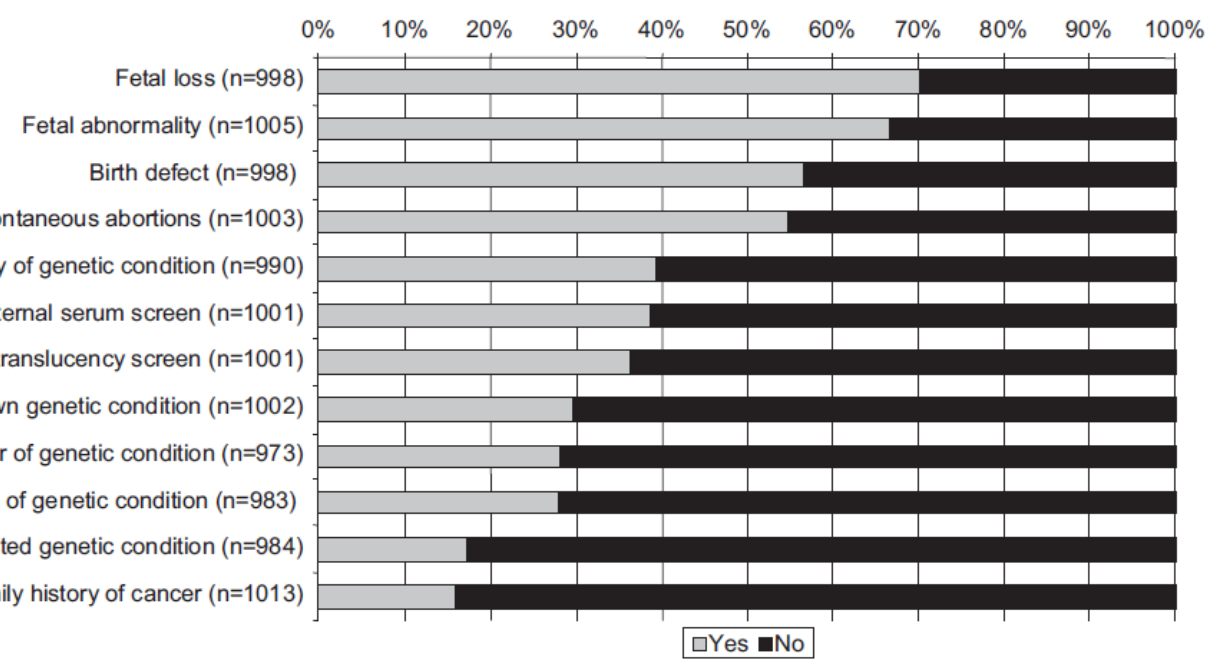


Benjamin, C.M., Anionwu, E.N., Kristoffersson, U., Kate, L.P. ten, Plass, A.M.C., Nippert, I., Julian-Reynier, C., Harris, H.J., Schmidtke, J., Challen, K., Calefato, J.M., Waterman, C., Powell, E., Harris, R. Educational priorities and current involvement in genetic practice: a surveyef 7 midwives in the Netherlands, UK and Sweden. Midwifery: 2009, 25(5), 483-499

Figure 3 Midwives' self-reported frequency of skills or procedures associated with genetic information. CVS, chorionic villus sampling.

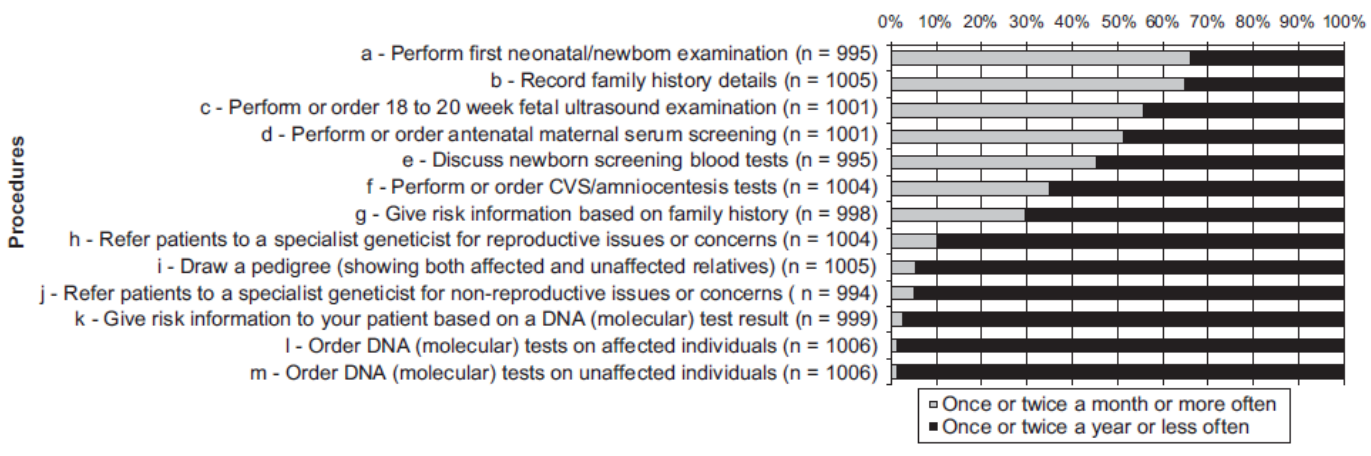

Figure 4 All countries' self-reported confidence in performing procedures involving genetic knowledge and skills (ranging from procedures/skills with most confidence to those with least confidence ).

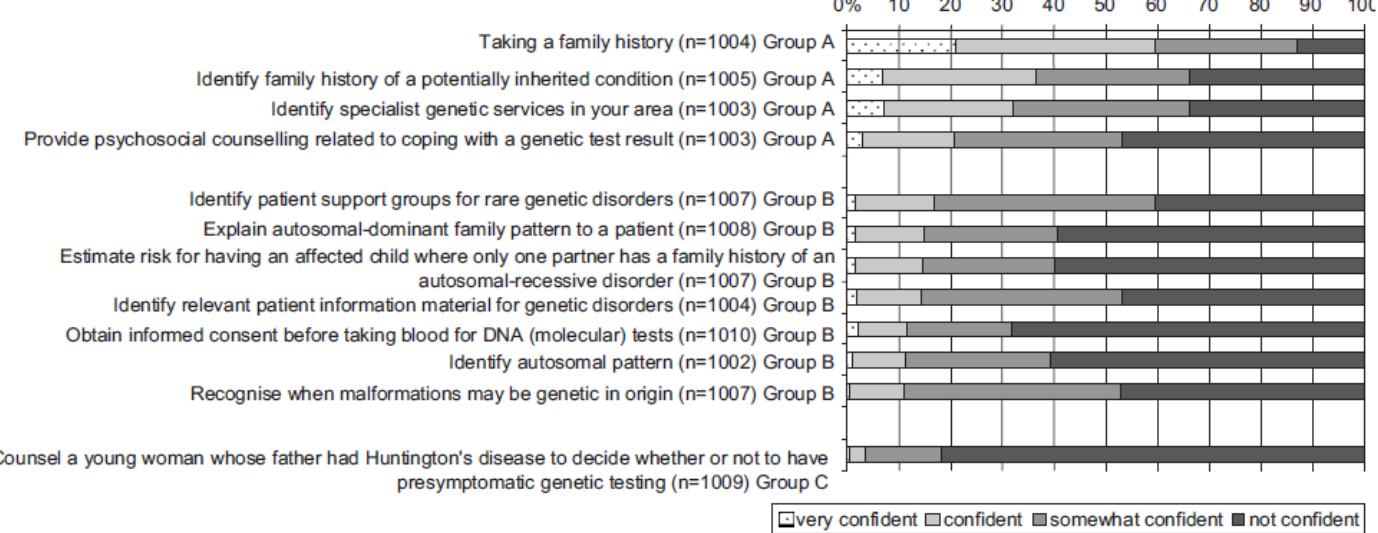


Benjamin, C.M., Anionwu, E.N., Kristoffersson, U., Kate, L.P. ten, Plass, A.M.C., Nippert, I., Julian-Reynier, C., Harris, H.J., Schmidtke, J., Challen, K., Calefato, J.M., Waterman, C., Powell, E., Harris, R. Educational priorities and current involvement in genetic practice: a survey $f$ midwives in the Netherlands, UK and Sweden. Midwifery: 2009, 25(5), 483-499

Table 4 Differences in confidence relating to the same procedure/skill between countries.

\begin{tabular}{|c|c|c|c|c|c|c|c|c|}
\hline Procedure & Order & $\%$ & $\begin{array}{l}\mathrm{NL} \\
\text { order }\end{array}$ & NL $\%$ & $\begin{array}{l}\text { SE } \\
\text { order }\end{array}$ & SE $\%$ & UK order & UK \% \\
\hline \multicolumn{9}{|l|}{ Group A } \\
\hline Taking a family history & 1 & 60 & 1 & 80 & 1 & 36 & 1 & 57 \\
\hline $\begin{array}{l}\text { Identify family history of a } \\
\text { potentially inherited condition }\end{array}$ & 2 & 36 & 2 & 65 & 7 & 7 & 2 & 31 \\
\hline $\begin{array}{l}\text { Identify specialist genetic services in } \\
\text { your area }\end{array}$ & 3 & 32 & 4 & 38 & 2 & 33 & 3 & 27 \\
\hline $\begin{array}{l}\text { Provide psychosocial counselling } \\
\text { related to coping with a genetic test } \\
\text { result }\end{array}$ & 4 & 21 & 3 & 39 & 5 & 17 & 11 & 6 \\
\hline \multicolumn{9}{|l|}{ Group B } \\
\hline $\begin{array}{l}\text { Identify patient support groups for } \\
\text { rare genetic disorders }\end{array}$ & 5 & 17 & 9 & 17 & 4 & 20 & 5 & 14 \\
\hline $\begin{array}{l}\text { Explain autosomal-dominant family } \\
\text { pattern to a patient }\end{array}$ & 6 & 15 & 5 & 34 & 10 & 3 & 10 & 6 \\
\hline $\begin{array}{l}\text { Estimate risk for having an affected } \\
\text { child where only one partner has a } \\
\text { family history of an autosomal- } \\
\text { recessive disorder }\end{array}$ & 7 & 15 & 6 & 26 & 11 & 3 & 7 & 12 \\
\hline $\begin{array}{l}\text { Identify relevant patient } \\
\text { information material for genetic } \\
\text { disorders }\end{array}$ & 8 & 14 & 11 & 8 & 3 & 23 & 6 & 13 \\
\hline $\begin{array}{l}\text { Obtain informed consent for DNA } \\
\text { (molecular) tests }\end{array}$ & 9 & 12 & 10 & 12 & 6 & 9 & 4 & 14 \\
\hline Identify an autosomal pattern & 10 & 11 & 7 & 23 & 9 & 3 & 9 & 6 \\
\hline $\begin{array}{l}\text { Recognise when malformations may } \\
\text { be genetic in origin }\end{array}$ & 11 & 11 & 8 & 19 & 8 & 4 & 8 & 8 \\
\hline \multicolumn{9}{|l|}{ Group C } \\
\hline $\begin{array}{l}\text { Counsel a young woman whose } \\
\text { father had Huntington's disease to } \\
\text { decide whether or not to have } \\
\text { presymptomatic genetic testing }\end{array}$ & 12 & 4 & 12 & 5 & 12 & 2 & 12 & 3 \\
\hline
\end{tabular}

NL, The Netherlands; SE, Sweden; UK, United Kingdom. 
Benjamin, C.M., Anionwu, E.N., Kristoffersson, U., Kate, L.P. ten, Plass, A.M.C., Nippert, I., Julian-Reynier, C., Harris, H.J., Schmidtke, J., Challen, K., Calefato, J.M., Waterman, C., Powell, E., Harris, R. Educational priorities and current involvement in genetic practice: a survey of 7 midwives in the Netherlands, UK and Sweden. Midwifery: 2009, 25(5), 483-499

Table 5 Factors significantly associated with increased confidence in genetic procedures.

\begin{tabular}{|c|c|c|c|c|}
\hline Genetic procedure & $\begin{array}{l}\text { Significantly associated } \\
\text { variables in the model }\end{array}$ & $\begin{array}{l}\text { Regression } \\
\text { coefficient }\end{array}$ & $\begin{array}{l}\text { Odds } \\
\text { ratio }\end{array}$ & p-Value \\
\hline Taking a family history ( $\mathrm{n}=975$ ) & $\begin{array}{l}\text { Lower age } \\
\text { Having genetic education } \\
\text { More clients seen per week } \\
\text { More frequent genetic cases }\end{array}$ & $\begin{array}{l}-6.03 \\
0.551 \\
0.369 \\
0.652\end{array}$ & $\begin{array}{l}0.547 \\
1.735 \\
1.447 \\
1.919\end{array}$ & $\begin{array}{l}0.000 \\
0.013 \\
0.040 \\
0.000\end{array}$ \\
\hline $\begin{array}{l}\text { Identify family history of a } \\
\text { potentially inherited condition } \\
(n=972)\end{array}$ & $\begin{array}{l}\text { Lower age } \\
\text { Having genetic education } \\
\text { Shorter career } \\
\text { More frequent genetic cases }\end{array}$ & $\begin{array}{c}-0.481 \\
0.593 \\
-0.373 \\
0.820\end{array}$ & $\begin{array}{l}0.618 \\
1.809 \\
0.689 \\
2.270\end{array}$ & $\begin{array}{l}0.012 \\
0.024 \\
0.011 \\
0.000\end{array}$ \\
\hline $\begin{array}{l}\text { identify an autosomal-dominant } \\
\text { pattern }(n=969)\end{array}$ & $\begin{array}{l}\text { Shorter career } \\
\text { More frequent genetic cases }\end{array}$ & $\begin{array}{l}-0.564 \\
1.077\end{array}$ & $\begin{array}{l}0.569 \\
2.935\end{array}$ & $\begin{array}{l}0.06 \\
0.00\end{array}$ \\
\hline $\begin{array}{l}\text { Explain autosomal-dominant } \\
\text { family pattern to a patient } \\
(n=970)\end{array}$ & $\begin{array}{l}\text { Lower age } \\
\text { Having genetic education } \\
\text { More clients seen per week } \\
\text { More frequent genetic cases }\end{array}$ & $\begin{array}{l}-0.716 \\
1.285 \\
0.437 \\
0.792\end{array}$ & $\begin{array}{l}0.489 \\
3.615 \\
1.547 \\
2.207\end{array}$ & $\begin{array}{l}0.07 \\
0.014 \\
0.043 \\
0.000\end{array}$ \\
\hline $\begin{array}{l}\text { Estimate risk for a couple where } \\
\text { one parent has a family history } \\
\text { of cystic fibrosis ( } n=974 \text { ) }\end{array}$ & $\begin{array}{l}\text { Having genetic education } \\
\text { Shorter career } \\
\text { More frequent genetic cases }\end{array}$ & $\begin{array}{c}1.533 \\
-0.536 \\
1.040\end{array}$ & $\begin{array}{l}4.631 \\
0.585 \\
2.830\end{array}$ & $\begin{array}{l}0.010 \\
0.004 \\
0.000\end{array}$ \\
\hline $\begin{array}{l}\text { Recognise when malformations } \\
\text { may be genetic in origin } \\
(n=975)\end{array}$ & $\begin{array}{l}\text { Shorter career } \\
\text { More frequent genetic cases }\end{array}$ & $\begin{array}{c}-0.491 \\
1.044\end{array}$ & $\begin{array}{l}0.612 \\
2.839\end{array}$ & $\begin{array}{l}0.019 \\
0.000\end{array}$ \\
\hline $\begin{array}{l}\text { Council a young woman } \\
\text { regarding Huntington's disease } \\
\text { predictive testing ( } n=973 \text { ) }\end{array}$ & More frequent genetic cases & 1.213 & 3.362 & 0.001 \\
\hline $\begin{array}{l}\text { Provide psychosocial counselling } \\
\text { related to coping with a genetic } \\
\text { test result }(n=970)\end{array}$ & $\begin{array}{l}\text { More clients seen per week } \\
\text { More frequent genetic cases }\end{array}$ & $\begin{array}{l}0.507 \\
0.650\end{array}$ & $\begin{array}{l}1.66 \\
1.916\end{array}$ & $\begin{array}{l}0.08 \\
0.00\end{array}$ \\
\hline $\begin{array}{l}\text { Identify patient support groups } \\
\text { for rare genetic disorders } \\
(n=976)\end{array}$ & $\begin{array}{l}\text { Increased age } \\
\text { More frequent genetic cases }\end{array}$ & $\begin{array}{l}0.462 \\
0.523\end{array}$ & $\begin{array}{l}1.587 \\
1.687\end{array}$ & $\begin{array}{l}0.018 \\
0.003\end{array}$ \\
\hline $\begin{array}{l}\text { Identify relevant patient } \\
\text { information material for genetic } \\
\text { disorders }(n=970)\end{array}$ & Increased age & 0.654 & 1.923 & 0.001 \\
\hline $\begin{array}{l}\text { Identify specialist genetic } \\
\text { services in your area }(n=973)\end{array}$ & $\begin{array}{l}\text { Having genetic education } \\
\text { Longer career } \\
\text { More frequent genetic cases }\end{array}$ & $\begin{array}{l}0.747 \\
0.319 \\
0.544\end{array}$ & $\begin{array}{l}2.110 \\
1.375 \\
1.722\end{array}$ & $\begin{array}{l}0.006 \\
0.026 \\
0.000\end{array}$ \\
\hline $\begin{array}{l}\text { Obtaining informed consent for } \\
\text { a DNA (molecular) test }(n=975)\end{array}$ & More frequent genetic cases & 0.417 & 1.517 & 0.044 \\
\hline $\begin{array}{l}\text { Selection of variables: } \\
\text { Binary outcome } \\
\text { Possible associated variables: }\end{array}$ & $0=$ Less confident & \multicolumn{2}{|c|}{$1=$ more confident } & \\
\hline $\begin{array}{l}\text { Age } \\
\text { Education } \\
\text { Length of career } \\
\text { Number of clients } \\
\text { Number of genetic cases }\end{array}$ & $\begin{array}{l}0 \leqslant 50 \text { years } \\
0=\text { no education } \\
0 \leqslant 20 \text { years } \\
0 \leqslant 50 / \text { week } \\
0=\text { up to three times a year }\end{array}$ & $\begin{array}{l}1>50 \text { years } \\
1=\text { some edu } \\
1>20 \text { years } \\
1>50 / \text { week } \\
1=\text { once a mo }\end{array}$ & or more & \\
\hline
\end{tabular}

